\title{
Correction to: A review of the trends in Ghana's power sector
}

Maame Esi Eshun ${ }^{1,2^{*}}$ and Joe Amoako-Tuffour ${ }^{1}$

\section{Correction to: Energy Sustain Soc (2016) 6:9 https://doi.org/10.1186/s13705-016-0075-y}

Following publication of the original article [1] there was a citation error to a statement which attributed the Institute of Statistical, Social and Economic Research (ISSER) as the origin and source of the estimated cost of Ghana's power crises. The 1st sentence of the 3rd paragraph of the article currently reads:

The Institute of Statistical, Social and Economic Research (ISSER) in 2014 estimated Ghana to lose between $\$ 320$ million and $\$ 924$ million per annum in productivity and economic growth due to the current power crises [2].

The sentence should read:

Power Systems Energy Consulting (PSEC) in 2010 estimated Ghana to lose between $\$ 320$ million and \$924 million per annum in productivity and economic growth due to the current power crises [17].

The incorrect reference used in that sentence:

ISSER (2005) Guide to Electric Power in Ghana. Resource Center for Energy Economics and Regulation. Institute of Statistical, Social and Economic Research, University of Ghana, Legon.
The reference should instead read:

Power Systems Energy Consulting (2010) Ghana Wholesale Power Reliability Assessment. Final Report, March 2010.

This has now been included in this correction article.

\section{Author details \\ ${ }^{1}$ Research Department, African Center for Economic Transformation, Accra, Ghana. ${ }^{2}$ Present Address: Research Department, Public Utilities Regulatory Commission, Accra, Ghana.}

Published online: 21 October 2020

\section{References}

1. Eshun ME, Amoako-Tuffour J (2016) A review of the trends in Ghana's power sector. Energy Sustain Soc 6:9. https://doi.org/10.1186/s1370 5-016-0075-y

2. ISSER (2005) Guide to electric power in Ghana. Resource Center for Energy Economics and Regulation. Institute of Statistical, Social and Economic Research, University of Ghana, Legon

17. Power Systems Energy Consulting (2010) Ghana wholesale power reliability assessment. Final Report.

\section{Publisher's Note}

Springer Nature remains neutral with regard to jurisdictional claims in published maps and institutional affiliations. original author(s) and the source, provide a link to the Creative Commons licence, and indicate ifchanges were made. The images or other third party material in this article are included in the article's Creative Commonslicence, unless indicated otherwise in a credit line to the material. If material is not included in the article's Creative Commonslicence and your intended use is not permitted by statutory regulation or exceeds the permitted use, you will need to obtainpermission directly from the copyright holder. To view a copy of this licence, visit http://creativecommons.org/licenses/by/4.0/.The Creative Commons Public Domain Dedication waiver (http://creativeco mmons.org/publicdomain/zero/1.0/) applies to thedata made available in this article, unless otherwise stated in a credit line to the data. 